\title{
First perissodactyl footprints from Flysch deposits of the Barail Group (Lower Oligocene) of Manipur, India
}

\author{
Hemanta Singh Rajkumar ${ }^{1, *}$ and Hendrik Klein ${ }^{2}$ \\ ${ }^{1}$ United College, Manipur University, Manipur, India. \\ ${ }^{2}$ Saurierwelt Paläontologisches Museum, D-92318 Neumarkt, Germany. \\ ${ }^{*}$ Corresponding author.e-mail: mohnarooprajkumar@gmail.com
}

Two pes imprints of a perissodactyl mammal constituting a single step of a trackway have recently been discovered in Oligocene Flysch deposits of the Barail Group in Manipur, India. The tridactyl, mesaxonic imprints ( $\sim 7 \mathrm{~cm}$ in length) show strong similarities to footprints known from the Paleogene of China and can be attributed to a tapiroid, rhinocerotoid or equoid trackmaker. This is the first record of perissodactyl footprints from the Lower Oligocene of India and the first evidence of mammals in the Barail Group of the age. Remarkable is the occurrence in a marginal marine setting, whereas other known perissodactyl footprints from the Eocene-Oligocene in particular from North America, Europe and China come from fluvio-lacustrine strata.

\section{Introduction}

Compared with the footprints of Mesozoic dinosaurs, Cenozoic vertebrate traces are still less studied and often do not attract the same attention of ichnological research. However, in recent years, their potential for paleobiogeography, paleoecology, and biostratigraphy was recognized, and a growing number of papers that focus especially on mammal tracks from the Tertiary and Pleistocene (Vialov 1965, 1966; Demathieu et al. 1984; Kordos 1985; McCrea et al. 2004; Hunt and Lucas 2007; Lucas 2007; McDonald et al. 2007) have been published. From the Tertiary, most records come from the Neogene, whereas Paleogene localities are less abundant (McDonald et al. 2007). Important surfaces with footprints of brontotheres, tapirs, rhinoceroses, ancient horses and other ungulates as well as bird tracks from the EoceneOligocene are known from North America, South America, Europe and China (Lockley and Hunt 1995; Lockley et al. 1999; Lockley and Meyer 1999;
Xing et al. 2013). Some trackbearing units of South America and China were originally mistaken for Mesozoic deposits, but their stratigraphic age is now identified as Cenozoic (Lockley et al. 1999; Melchor et al. 2002, 2013; DeValais and Melchor 2008). Thus far, the Cenozoic footprint record from India is scarce. From the Siwaliks of India, footprints of Miocene artiodactyls have been described by West et al. (1983). Here we describe the first mammal (perissodactyl) footprints from Lower Oligocene Flysch deposits of the Barail Group in Manipur, India. The ichnofossils supplement the skeletal record of perissodactyls from the Paleogene of South Asia that comprises numerous tapiromorph forms (Antoine et al. 2003; Holroyd et al. 2006; Missiaen and Gingerich 2012).

\section{Geological setting}

The Indo-Myanmar Ranges (IMR) is thought to be the northern elongation of the Indonesian island

Keywords. Perissodactyl footprints; Lower Oligocene; Flysch deposit; Laisong Formation; Manipur; India. 
arc. It is an arcuate shaped tectonic belt having a convexity towards west. Brunschweiler (1966) described the region in terms of three major lithostratigraphic units: the Naga Metamorphic Complex, the Naga Hills Flysch and the Upper Chindwin Molásse. The Naga Hills is the northernmost segment of the IMR and trending nearly NE-SW. The segment mainly consists of the Naga-Patkoi Hills of Nagaland and the northern part of the Manipur Hills. Acharyya et al. (1986) described the geological and tectonic setting of the Naga Hills in terms of two distinct longitudinal belts; the Central Naga Hills Palaeogene Flysch sediments and the Naga-Chin Hills Ophiolite Belt. The Central Naga Hill Palaeogene Flysch sediments, which can simply be referred to as the Flysch Belt are principally made up of sediments of Disang and Barail groups, constituting the western part of the Naga Hills segment. Most of the lithostratigraphic units in the region occur in the form of an imbricate thrust system where older lithostratigraphic units lie above the younger ones (Soibam 2000; Soibam and Pradipchandra 2006). The principal lithostratigraphic units of the Flysch Belt in the state of Manipur are composed of turbidite sediments of the Disang and Barail groups and molásse sediments of the Surma and Tipam groups, respectively (table 1). The Disang Group (Upper Cretaceous to Upper Eocene) consists of a monotonous sequence of dark grey to black splintery shales, and occasional rhythmites of shales and siltstones/finegrained sandstones, forming the principal lithostratigraphic units of the eastern half of the state of Manipur $\left(23^{\circ} 50^{\prime}-25^{\circ} 55^{\prime} \mathrm{N}\right.$ latitudes and $093^{\circ} 00^{\prime}-$ $094^{\circ} 45^{\prime} \mathrm{E}$ longitudes). The Barail Group, mainly Oligocene in age, with a possible range to the Upper Eocene, consists of $\sim 3000 \mathrm{~m}$ thick arenaceous beds intercalated with shales and carbonaceous shales, silty shales and siltstones intercalated with thin shale beds and sandstones that rest on the Disang Group. The occurrence of Barail sediments in the state mainly starts from the western foothill regions of the Imphal Valley (figure 1). The basal part of the Barail Group has a gradational (with local tectonic) contact with the Disang Group (Soibam 2000). This gradational contact is related with a gradual change from dominantly argillaceous deep marine to a mainly arenaceous shallow marine depositional environment (Guleria et al. 2005). The Barail Group has been divided into three formations namely the Laisong, Jenam, and Renji (Evans 1932). The Laisong Formation, about $1200 \mathrm{~m}$ thick, is characterized by alternations of shale, silty shale, siltstone and fine to medium grained sandstones, giving rise to a typical turbidite sequence (figure 2). This formation contains abundant and varied sedimentary structures such as ripple marks, undulating bedding, cross-stratification, hummocky crossstratifications, herringbone structures, etc., indicating wave and current influence, and deposition above storm wave base. The studied section reflects a transition zone and could represent a large fluctuation in the sedimentation rate. Therefore, sedimentary facies deposited above storm wavebase comprises large sedimentary structures, otherwise they are characteristic of sediments formed below the storm wave-base level. The footprints described herein come from a silty shale near the base of the Laisong Formation at the Gelmon locality $\left(23^{\circ} 44^{\prime} 19.9^{\prime \prime} \mathrm{N}-092^{\circ} 40^{\prime} 16.5^{\prime \prime} \mathrm{E}\right.$, elevation of $905 \mathrm{~m}$ ). The Laisong Formation section at Gelmon locality may be considered to be of Lower Oligocene age taking reference to earlier studies carried out in the state in sections that belong to Upper Disang (Middle to Upper Eocene) and Lower Barail (Upper Eocene to Oligocene) transition sections. For example, Kachhara et al. (2000) treated the Biozone B at Thoubal (Kabrang Hill, $24^{\circ} 39^{\prime} 67^{\prime \prime} \mathrm{N}-094^{\circ} 00^{\prime} 57^{\prime \prime} \mathrm{E}$; Kaina Hill, $24^{\circ} 41^{\prime} 20^{\prime \prime} \mathrm{N}-094^{\circ} 01^{\prime} 31^{\prime \prime} \mathrm{E}$ ) as the lowermost lithological contact of the Barail Group (Laisong Formation) with the Upper Disang Formation based on bivalves such as Cardium, Chlamys, Lucina, Ostrea, Trigonia, Pinna, Spondylus, Tellina, Pecten and Turritella. However, a proper age to this formation may only be assigned after proper dating of the sediments, which has not been done so far.

\section{Tetrapod footprints}

\subsection{Material}

Two successive footprints of a trackway catalogued as MSM-1 and displayed in the Manipur State Museum (figure 3). A cast of the specimen has been made using modelling clay and is kept at the Geological Museum, United College, Manipur.

\subsection{Locality and horizon}

Silty shale beds with lingoid ripples and scour marks, about $30 \mathrm{~mm}$ thick, at Gelmon locality (Manipur, India). Track-bearing layer close to the base of the Lower Laisong Formation of the Barail Group.

\subsection{Description}

Two tridactyl imprints, probably those of the pes, representing a single step (right-left) of a trackway (pace length $=18.6 \mathrm{~cm}$ ) (figure $3 \mathrm{~A}$ ). They have been preserved as moderately impressed concave epireliefs. Their overall shape is mesaxonic 
Table 1. Stratigraphic succession of Manipur (modified after Soibam 2000).

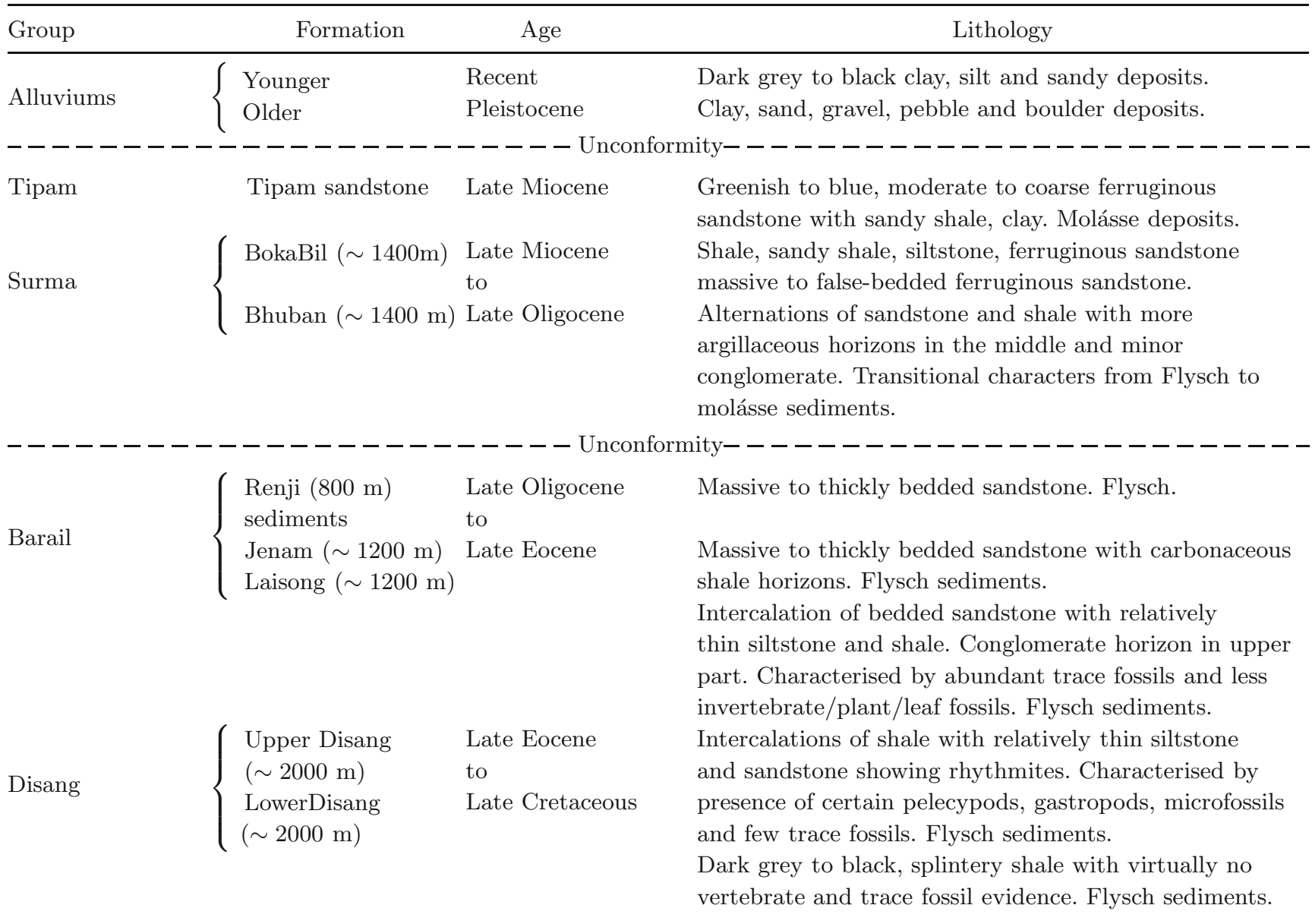

Ukhrul limestone Late Cretaceous Limestone, chert, conglomerate characterised by abundant microfossils - foraminifers and radiolarians.

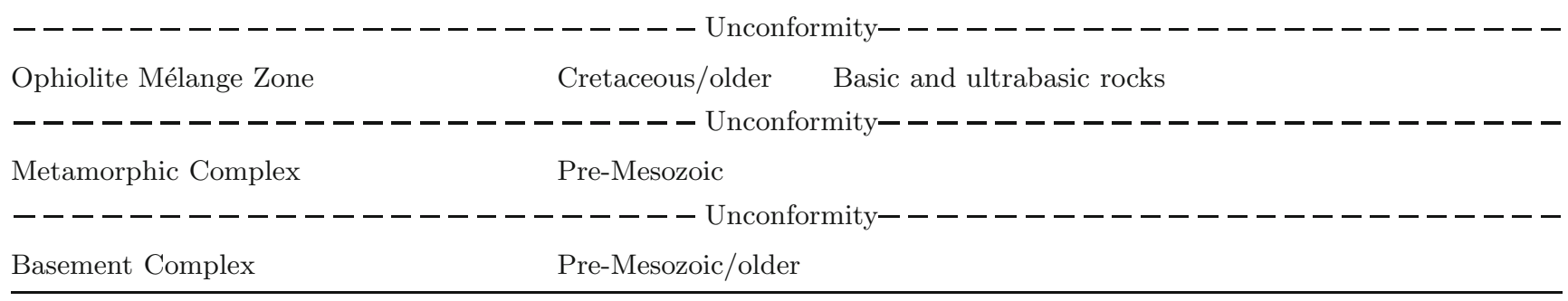

with digit trace III being longest and projecting more anteriorly compared with lateral digits. The first imprint (figure $3 \mathrm{~A}-\mathrm{ii}$ ) is $6.3 \mathrm{~cm}$ in length and $8.2 \mathrm{~cm}$ in width (length/width $=0.8$ ), the better preserved second imprint (figure $3 \mathrm{~A}-\mathrm{i}$ ), $7 \mathrm{~cm}$ in length and $7.7 \mathrm{~cm}$ in width (length/width $=$ 0.9). The digit traces are moderately spread. Their divarication was measured in the well-preserved second imprint with $41^{\circ}$ (II-III), $18^{\circ}$ (III-IV) and $58^{\circ}$ (II-IV). They terminate in broad rounded, hoof-like impressions. In particular, the digit trace III of the second imprint shows three distinct circular to oval impressions of the digital pads and the distal hoof. The digit traces are embedded in a broad oval, faint impression of the sole that shows a posteriorly concave embayment forming a bilobate posterior margin. The embayment is positioned in line with digit trace III. There is no indication of the presence of manus imprints.

\section{Discussion}

The tridactyl, mesaxonic shape and the hoof impressions indicate a perissodactyl mammal as the trackmaker. Footprints of perissodactyls are known, for example, from Upper Eocene deposits of Trans-Pecos, Texas, USA and have been assigned to tapiroid, rhinocerotoid and brontotheroid group 


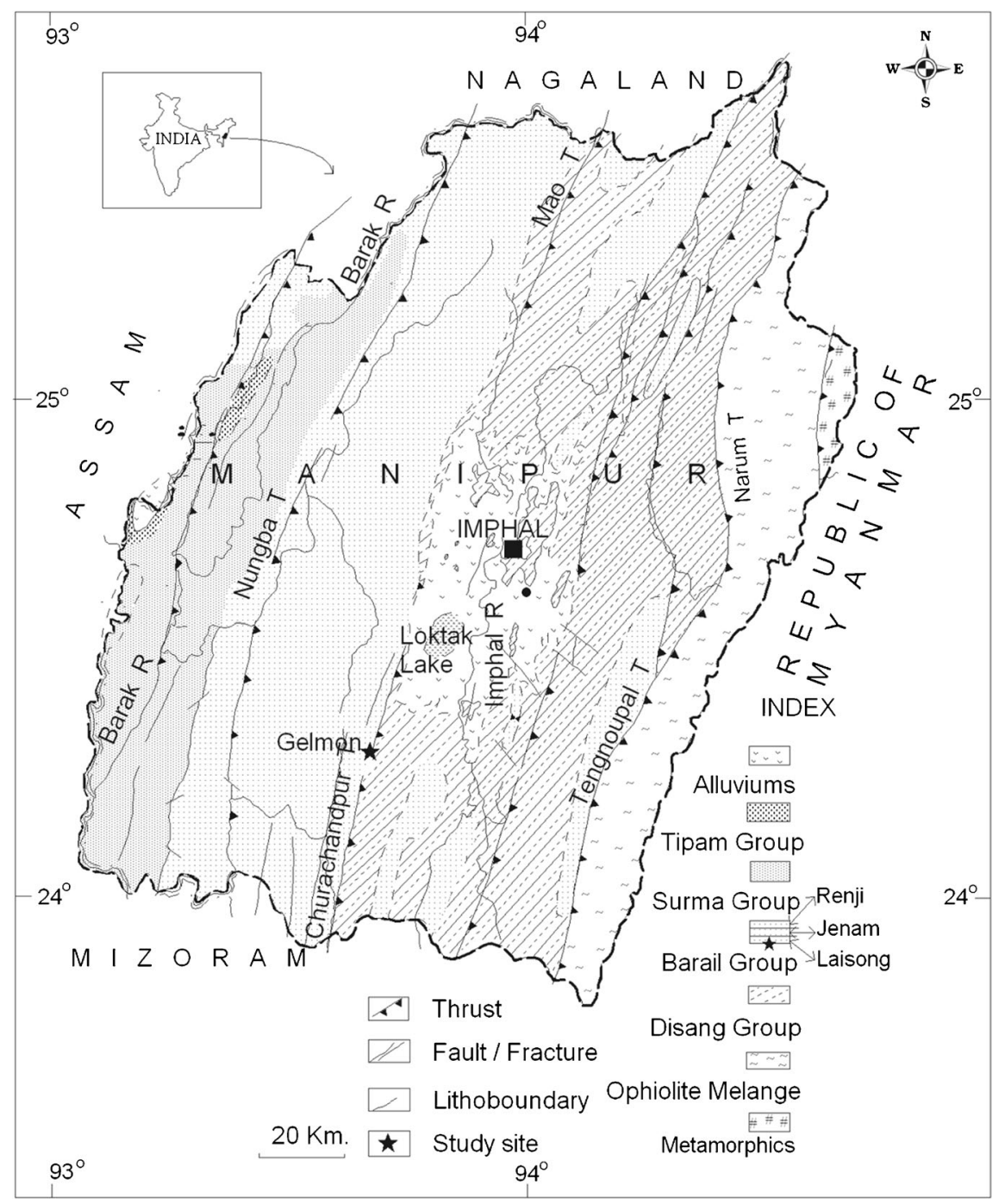

Figure 1. Geological map of Manipur (northeast India) indicating study (track) site.

trackmakers (Sarjeant and Langston 1994). Important surfaces with perissodactyl footprints come from the Eocene Chuckanut Formation and the Pudget Group of Washington (USA) (Mustoe 2002; Mustoe and Hopkins 2013). These tracks have been attributed to Hyracotherium-like equids and/or tapiroids, known also by a rich skeletal record from the North American west. Famous localities with perissodactyl and other ungulate footprints are in the Duchesne, Uinta, Green River and Debeque formations of Utah and Colorado (USA) as well as in Paleogene (Eocene-Oligocene) deposits of France, Spain and Peru (Demathieu et al. 1984; Lockley and Hunt 1995; Hamblin et al. 1998, 1999; Lockley and Meyer 1999; see Lockley et al. 1999 for overview). The locality in the Apt Basin of southeastern France which is in Lower Oligocene calcareous lake deposits, shows trackways with typical pes and manus imprints of a rhinocerotoid and was named Rhonzotherichnus (Demathieu et al.
1984). However, the imprints are much larger compared with those from Manipur and the middle digit trace is more broad with a sharp distal edge of the hoof. One of the best localities with Cenozoic tracks, that also contains perissodactyl footprints, is in the lower Miocene of Hungary (Kordos 1985; Szarvas 2007). The well-preserved tracks of rhinocerotoids are also larger than those of the Manipur specimen and the middle digit has a broad-oval shape. From Asia, perissodactyl footprints are known from Eocene and Miocene deposits of Iran (Ataabadi 2007) and especially from the Xinjiang Province of China (Lockley et al. 1999). The tridactyl footprints from Iran show a more extended heel portion with a posteriorly convex margin and are over $20 \mathrm{~cm}$ in size. By their shape and size, the imprints described herein resemble the footprints from China. Both are mesaxonic tridactyl with a bilobate posterior margin. The latter are $6 \mathrm{~cm}$ 


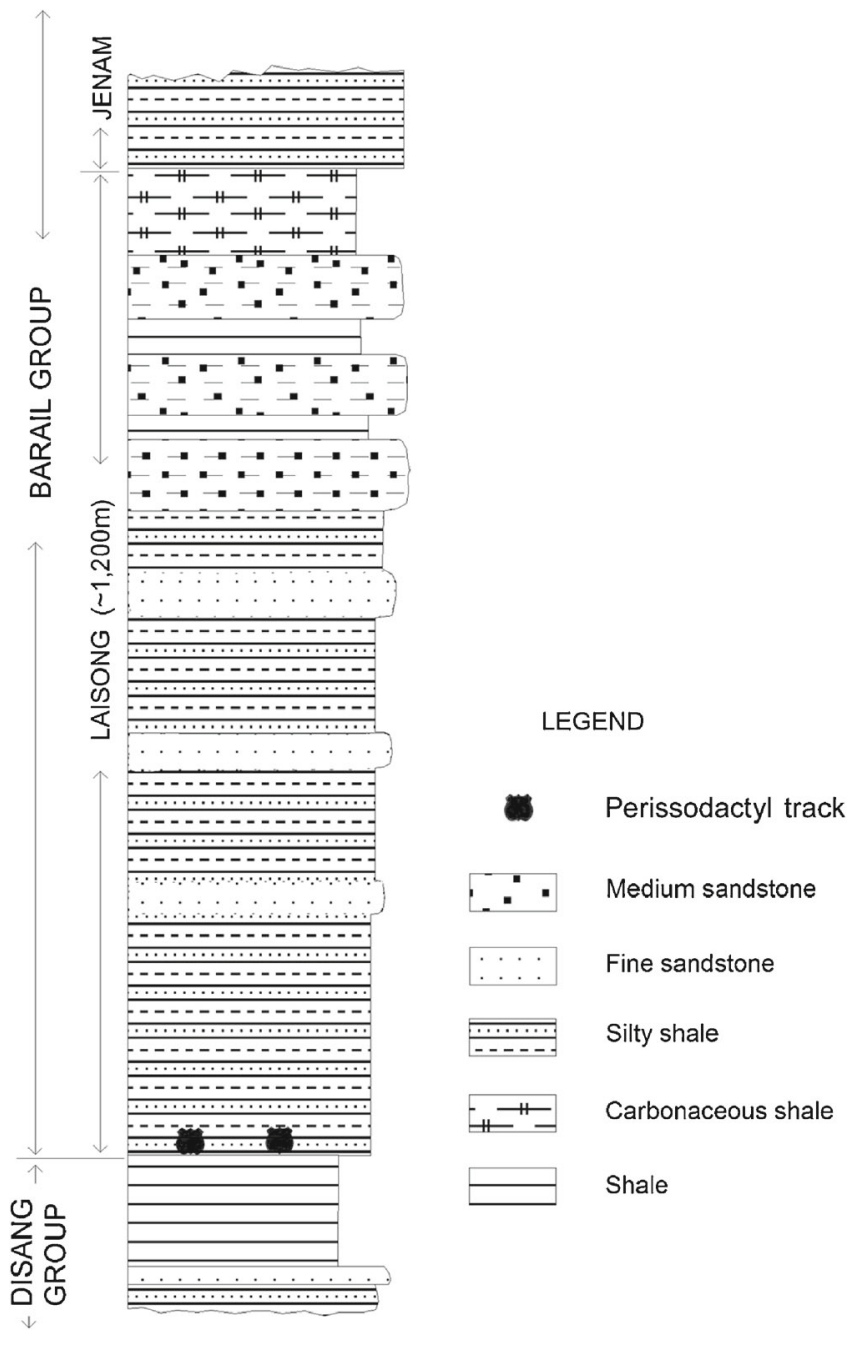

Figure 2. Lithostratigraphic section showing the position of the perissodactyl track horizon.

in length and $8 \mathrm{~cm}$ in width, which matches the measurements given for the Barail specimen above. On the contrary, perissodactyl footprints described from North America and Europe mostly show a posteriorly convex and continuous margin (Lockley et al. 1999; Mustoe 2002). Small tridactyl imprints of perissodactyls have been described from the Oligocene of Spain by Murelaga et al. (2000) and Astibia et al. (2007), but all have an elongate 'heel' and a convex posterior margin, whereas the imprints from the Barail Group are relatively short, broad and concave posteriorly. The lack of a manus imprint in the Barail specimen may be due to overstep by the pes which is a common feature in mammal tracks (Mustoe 2002). Costeur et al. (2009) figure footprints of larger rhinocerotoids from the Oligocene of southeastern France, but these have a mediolaterally extended hoof impression on the third digit which is characteristic of rhinoceros tracks. By their overall shape, the perissodactyl footprints from the Barail Group can rather be assigned to small equoids or tapiroids, even if basal rhinocerotoids cannot be excluded. Ichnotaxonomically, perissodactyl footprints have been assigned to different ichnogenera such as Apoxypus, Rhinoceripeda, Plagiolophus, Plagiolophustipus, Lophiopus or Palaeotheripus. In most cases, a differentiation is difficult to make and the ichnotaxonomy will certainly need revision. Also, further prospection at the Gelmon footprint locality and nearby areas might yield larger samples that permit a more detailed determination. Therefore, the footprints from the Barail Group are not assigned here to a distinct ichnotaxon.

\section{Conclusions}

The footprints from the Laisong Formation of the Barail Group are the first record of Lower Oligocene perissodactyl tracks from India, strongly resembling those previously described from Xinjiang Province of China. Remarkable is the paleoenvironment which is considered as marginal marine. Singh et al. (2012) indicated a tropical to sub-tropical climate for the depositional basin of Laisong sediments. The depositional setting/environment of the Upper Disang-Lower Barail transition sediments was considered as moist tropical with high humidity by Guleria et al. (2005) based on morphologies of Paleogene monocot and dicot plant leaves from Manipur such as Dicotylophyllum kainai sp. nov., Phoenicites indica sp. nov., Amesoneuron manipurensis sp. nov., Dicotylophyllum asymmetricum sp. nov., etc. These taxa differ from any known fossil dicotyledonous floras from various parts of India (Guleria and Mehrotra 1999; Mehrotra and Mandaokar 2000). It is likely that the source material of plant fossils came from the Myanmar landmass rather than from the Indian subcontinent. The similarities between the Laisong tracks and those from Xinjiang Province of China could be correlated to a continuous landmass connection between China and Myanmar during Lower Oligocene time, favouring a likely migration and dispersal of different vertebrates. However, this is only a speculative observation and based on a small sample of footprints, this cannot be proved presently. Interestingly, skeletal remains of middle Eocene perissodactyls (rhinocerotoids) from Myanmar show a relationship with coeval forms from North America and Asia (Holroyd et al. 2006). Vertebrate body fossils from the Indian subcontinent indicate a faunal exchange with other parts of Asia as well as with Europe (Antoine et al. 2003; Rose et al. 2006; Missiaen and Gingerich 2012). Further material and study is needed to explain this conclusively. It has to be noted that the deposition of plant fossils was prior to the subduction of the Indian plate beneath the Myanmar 
(A)

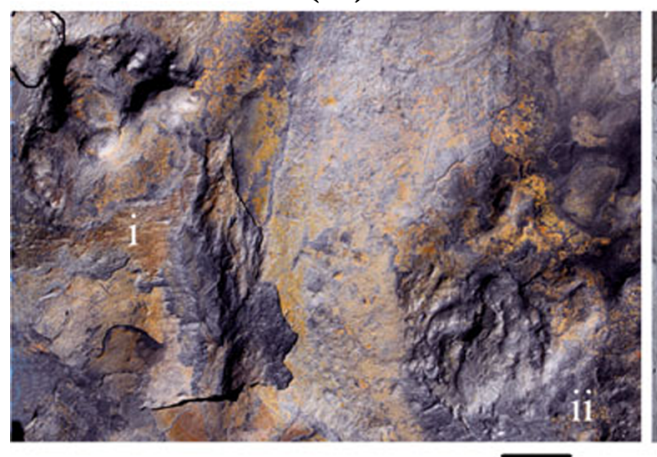

(C)

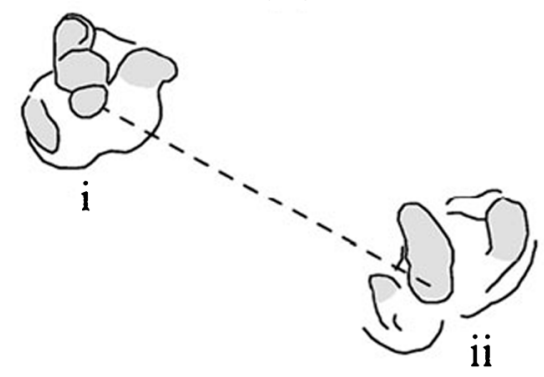

(E)

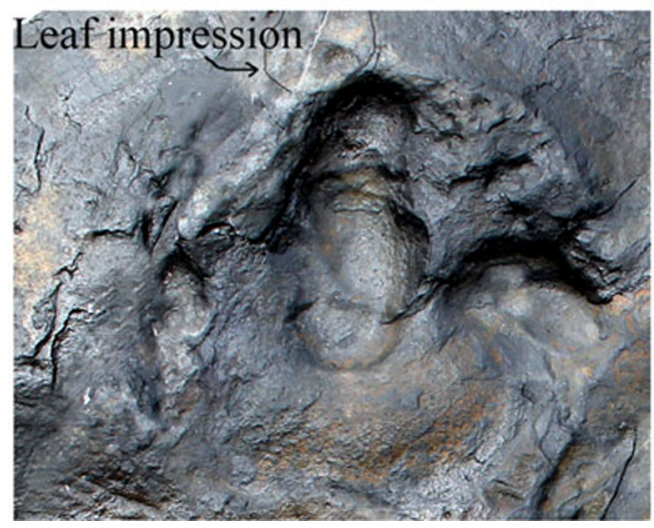

(B)

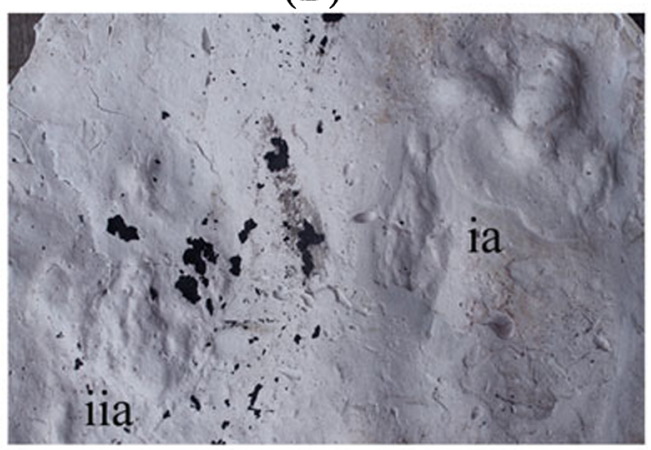

(D)

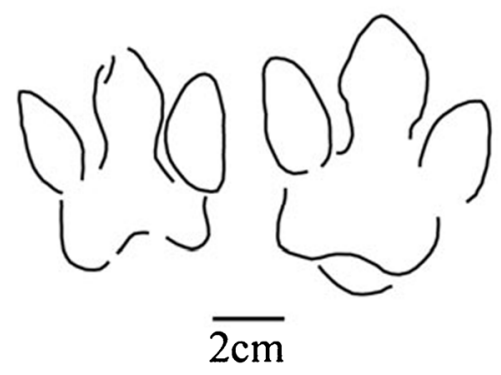

(F)

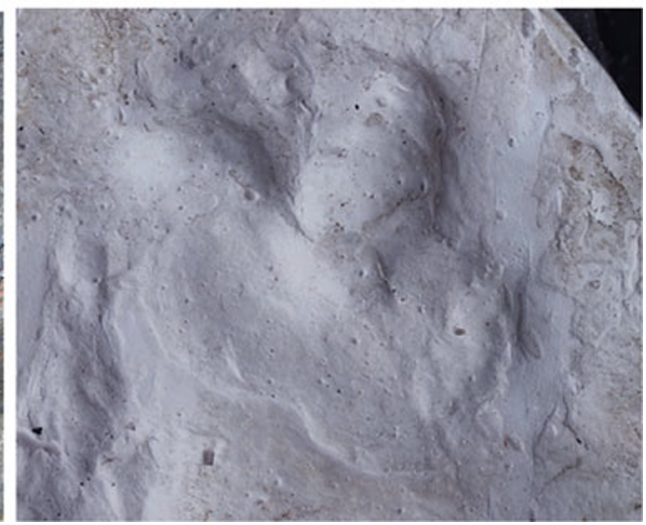

Figure 3. Pes tracks of a perissodactyl mammal (MSM-1) from the base of the Laisong Formation (Barail Group, Lower Oligocene) of Manipur (northeast India) preserved as concave epireliefs. (A) Photograph of footprints (i) left and (ii) right from partial trackway. (B) Cast of (A) where ia and iia are respectively the corresponding casts of tracks i and ii in (A). (C) Sketch of the partial trackway. (D) Perissodactyl pes imprints from the Paleogene of Xinjiang Province, China for comparison (after Lockley et al. 1999). (E) Close-up of pes i in (A); notice the leaf impression on the top left corner of (E). (F) Cast of (E).

micro-plate (cf. Soibam and Khuman 2008). Therefore, the exchange of terrestrial faunas between the Indian landmass and the Myanmar continental margin was very unlikely at that time. With respect to the palaeoenvironment, Rajkumar et al. (2008, 2012) reported a marginal marine depositional setting for the Laisong sediments and the trackbearing unit based on various invertebrateichnofossils. On the other hand, perissodactyl footprints from North America, Europe and China all come from fluviolacustrine deposits. The new discovery from Manipur indicates the wide distribution of the trackmakers that may have been early equoids, tapiroids or rhinocerotoids frequenting the subtropical to tropical Lower Oligocene coasts of the western Myanmar continental margin.

\section{Acknowledgements}

The authors are thankful to the DST-ESS, Govt. of India, New Delhi for the grant received vide 
no. IR/S4/ES-441/2009. The comments of George E Mustoe of Western Washington University, Bellingham, USA, Loïc Costeur of the Natural History Museum Basel, Switzerland and an anonymous reviewer are highly acknowledged as their comments helped us to improve the manuscript notably. Special thanks is due to G V R Prasad, Associate Editor, Journal of Earth System Science with whose comments the manuscript has been improved incredibly.

\section{References}

Acharyya S K, Mitra N D and Nandy D R 1986 Regional geology and tectonic settings of northeast India and adjoining regions; Geol. Surv. India Memoir 119 6-12.

Antoine P O, Ducrocq S, Marivaux L, Chaimanee Y, Crochet J Y, Jaeger J J and Welcomme J L 2003 Early Rhinocerotids (Mammalia, Perissodactyla) from SouthAsia and a review of the Holarctic Paleogene Rhinocerotid record; Canadian J. Earth Sci. 40(3) 365-374.

Astibia H, Pereda Superbiola X, Payros A, Murelaga X, Berreteaga A, Baceta J I and Badiola A 2007 Bird and mammal footprints from the Tertiary of Navarre (Western Pyrenees); Ichnos 14 175-184.

Ataabadi M M 2007 Cenozoic mammal footprints of Iran and their significance; New Mexico Museum of Natural History and Science Bulletin 42 251-259.

Brunschweiler R O 1966 On the geology of the Indo-Burma ranges; J. Geol. Soc. Australia 13 137-194.

Costeur L, Balme C and Legal S 2009 Early Oligocene mammal tracks from southeastern France; Ichnos 16 257-267.

Demathieu G, Ginsburg L, Guérin C and Truc G 1984 Etude paléontologique, ichnologique et paléoécologique du gisement oligocène de Saignon (bassin d'Apt, Vaucluse); Bulletin du Museum National d'Histoire naturel de, Paris 6(4) $153-183$.

De Valais S and Melchor R N 2008 Ichnotaxonomy of bird-like footprints: An example from the Late TriassicEarly Jurassic of northwest Argentina; J. Vertebrate Paleontology 28 145-159.

Evans P 1932 Explanatory notes to accompany a table showing the Tertiary successions in Assam; Trans. Mining and Geological Institute India $\mathbf{2 7}$ 155-260.

Guleria J S and Mehrotra R C 1999 On some plant remains from intertrappean localities of Seoni and Mandla districts of Madhya Pradesh, India; Palaeobotanist 47 68-87.

Guleria J S, Rajkumar H S, Mehrotra R C, Soibam I and Rajkumar K 2005 Palaeocene plant fossils of Manipur and their palaeoecological significance; Palaeobotanist 4 61-77.

Hamblin A H, Sarjeant W A S and Spalding D A E 1998 A remarkable mammal trackway in the Uinta Formation (late Eocene) of Utah; BYU Geology Studies 43 9-18.

Hamblin A H, Sarjeant W A S and Spalding D A E 1999 Vertebrate footprints in the Duchesne River and Uinta formations (Middle to Late Eocene), Uinta basin, Utah; Utah Geol. Surv. Misc. Publ. 99(1) 443-454.

Holroyd P A, Tsubamoto T, Egi N, Ciochon R L, Takai M, Tun S T, Sein C and Gunnell G F 2006 A rhinocerotid perissodactyl from the late middle Eocene Pondaung Formation, Myanmar; J. Vertebrate Paleontology 26(2) 491-494.

Hunt A P and Lucas S G 2007 Cenozoic vertebrate trace fossils of North America: Ichnofaunas, ichnofacies and biochronology; New Mexico Museum of Natural History and Science Bulletin 42 17-41.

Kachhara R P, Soibam I and Jamir N M 2000 Upper age limit of the Disang Group in Manipur; In: Proceeding Indian colloquium of micropalaeontology and stratigraphy; Bull. ONGC 37(2) 215-218.

Kordos L 1985 Footprints in the Lower Miocene sandstone of Ipolytarnóc; Geologica Hungarica 46 257-415.

Lockley M G and Hunt A P 1995 Dinosaur tracks and other fossil footprints of the western United States (New York: Columbia University Press), 338p.

Lockley M G and Meyer C A 1999 Dinosaur tracks and other fossil footprints of Europe (New York: Columbia University Press), 323p.

Lockley M G, Ritts B D and Leonardi G 1999 Mammal track assemblages from the Early Tertiary of China, Peru, Europe and North America; Palaios 14 398-404.

Lucas S G 2007 Cenozoic mammal footprint biostratigraphy and biochronology; New Mexico Museum of Natural History and Science Bulletin 42 103-111.

McCrea R T, Pemberton S G and Currie P J 2004 New ichnotaxa of mammal and reptile tracks from the upper Paleocene of Alberta; Ichnos 11 323-339.

McDonald H G, White R S, Lockley M G and Mustoe G E 2007 An indexed bibliography of Cenozoic vertebrate tracks; New Mexico Museum of Natural History and Science Bulletin 42 275-302.

Mehrotra R C and Mandaokar B D 2000 Leaf impressions from Oligocene sediments of Manmao, Tirap District, Arunachal Pradesh, India; Palaeobotanists 49 $311-315$.

Melchor R N, De Valais S and Genise J F 2002 Birdlike footprints from the Late Triassic; Nature 417 936938.

Melchor R N, De Valais S and Genise J F 2013 A late Eocene year for Late Triassic bird tracks; Nature 495 E1-E2.

Missiaen P and Gingerich P D 2012 New early Eocene tapiromorph perissodactyls from the Ghazij Formation of Pakistan, with implications for mammalian biochronology in Asia; Acta Palaeontologica Polonica 57(1) 21-34.

Murelaga X, Baceta J I, Astibia H, Badiola A and Pereda Superbiola X 2000 Icnitas de perisodáctylos en el Oligoceno de Navarra: Posición estratigráfica y sistemática; Geogaceta 27 15-18.

Mustoe G E 2002 Eocene bird, reptile and mammal tracks from the Chuckanut Formation, northwest Washington; Palaios 17 403-413.

Mustoe E and Hopkins D Q 2013 Mammal and bird tracks from the Eocene Puget Group, northwest Washington, USA; Ichnos 20(1) 36-42.

Rajkumar H S, Rodrígueze-Tovar F J and Soibam I 2008 Trace fossils of the upper Eocene-Lower Oligocene transition of the Manipur, Indo-Myanmar Ranges (northeast India); Turkish J. Earth Sci. 17 821-834.

Rajkumar H S, Khaidem K S and Soibam I 2012 Trace fossils and palaeoenvironment of Barail Flysch, Manipur, northeast India; Abstracts - Ichnia 3rd International Congress on Ichnology, St. John's, Newfoundland, 87p.

Rose K D, Smith T, Rana R S, Sahni A, Singh H, Missiaen P and Folie A 2006 Early Eocene (Ypresian) continental vertebrate assemblage from India, with description of a new anthracobunid (Mammalia, Tethytheria); J. Vertebrate Paleontology 26(1) 219-225.

Sarjeant W A S and Langston W Jr 1994 Vertebrate footprints and invertebrate traces from the Chadronian (Late Eocene) of Trans-Pecos Texas; Texas Memorial Museum Bulletin 36 1-95. 
Singh M C, Kushwaha R A S, Srivastava G and Mehrotra R C 2012 Plant remains from the Laisong Formation of Manipur; J. Geol. Soc. India 79 287-294.

Soibam I 2000 Structural and tectonic framework of Manipur; In: Souvenir X Manipur Science Congress, Imphal, pp. 26-37.

Soibam I and Pradipchandra M 2006 Analysis of drainage systems of Manipur and implications on the tectonics of the Indo-Myanmar Ranges; In: Himalaya (Geological Aspects), (ed.) Saklani P S, 4 281-302.

Soibam I and Khuman M 2008 Ophiolite of Manipur, $\mathrm{NE}$ India - an active continental margin ophiolite in the tectonic framework of Indo-Myanmar Ranges (Ab; AS101213L), 33rd International Geological Congress, Oslo, Norway (August 6-4).
Szarvas I 2007 Case study of the Ipolytarnoc tracksite, Hungary; New Mexico Museum of Natural History and Science Bulletin 42 303-307.

Vialov O S 1965 Stratigraphiya neogenovix molass predcarpatskogo probiga; Naukova Dumka, Part K, 191p (in Russian).

Vialov O S 1966 Sledy zhiznedeyatelnosti organizmow i ikh paleontologicheskoe znachenie; Naukova Dumka, 219p (in Russian).

West R M, Pamt T R, Hutchison J R and Conroy G C 1983 Fossil mammal footprints from the Siwaliks of south-central Asia; Curr. Sci. 52 12-16.

Xing L, Lockley M G and Falk A 2013 First record of Cenozoic bird footprints from East Asia (Tibet, China); Ichnos 20 19-23. 